\title{
Quo Vadis Reclamation Policy Development Bay Of Jakarta
}

\author{
Trubus Rahardiansah ${ }^{1 *}$ \\ ${ }^{1}$ Faculty of Law, Trisakti University, Jakarta, Indonesia
}

\begin{abstract}
The reclamation policy of the bay of Jakarta has been started since 1995 with the issuance of Presidential Decree no. 52 of 1995 on the North Coast Reclamation of Jakarta. Because in the implementation of many protests from the public, the Government canceled the policy of reclamation by issuing Presidential Regulation No. 54 of 2008 on Spatial Planning of Jakarta, Bogor, Depok, Tangerang, Bekasi, Puncak and Cianjur. However, in its development, the Provincial Government of DKI Jakarta issued Governor Regulation No. 58 of 2018 on the Establishment, Organization and Working Procedures of the North Coast Reclamation Management Coordinating Board of Jakarta. Surprisingly substantially the Governor's Regulation refers to Presidential Decree No. 52 of 1995 and implies that the reclamation project will continue. By using Mazmanian and Sabatier (1983) policy theory, namely: (1) tractability of the problems; (2) ability of statute to structure implementation; (3) nonstatutory variables affecting implementation, the implementation of reclamation policy has not been successful.
\end{abstract}

\section{Introduction and literature review}

Reclamation is an effort to get land by drying or hoarding a water so that land is produced in the form of land. According to Zaidiem (1995) [1] reclamation is an attempt to seize the sea for urban expansion. At a glance reclamation is to add land that can be used for various kinds of human needs. In this context, reclamation is a land use that is not economical as a matter of settlement, agriculture, industry, recreation and others, which includes soil preservation, preservation of water sources, barren land acquisition, drainage of swamps or valleys and tidal projects. Based on Law Number 27 of 2007 concerning Management of Coastal Areas and Small Islands, reclamation is defined as activities carried out in order to increase the benefits of land resources in terms of environmental and socio-economic perspectives by means of landfill or drainage.

The Jakarta Bay reclamation policy is a comprehensive effort carried out by the government in order to expand the residential area for the people of the capital considering the limited land space in the Jakarta area. In addition, the reason for reclamation aims to prevent the erosion of Jakarta's land by sea water, and to build several other city facilities.

\footnotetext{
* Corresponding author: trubus_rp@yahoo.com
} 
On the other hand the reclamation of the north coast of Jakarta is also intended to reorganize the coastal area and make Jakarta a waterfront city [2].

But in its implementation, the Jakarta Bay reclamation policy faces many complex problems, such as aspects of licensing, economic, social and environmental problems. Various problems arise due to various factors, particularly overlapping regulatory factors and changing policies. In addition, developers who invest also pay less attention to the impact of the physical and social environment, because only pursuing business interests without involving the fishing community [3].

In the context of policy, there are still two contradictory sources of law, namely Presidential Decree No. 52 of 1995 concerning the North Coast Reclamation of Jakarta as a support for the sustainability of reclamation projects that are contrary to Presidential Regulation No. 54 of 2008 concerning Spatial Planning Jakarta, Bogor, Bekasi, Tangerang, and Cianjur. In the regulation stated that the Presidential Decree Number 52 of 1995 as long as it relates to spatial aspects is no longer valid. Thus, juridically, the policy of reclamation projects is problematic because of the weak legal umbrella and lack of coordination between relevant departments and ministries and the lack of coordination between the central government and the provincial government of DKI Jakarta.

\section{Jakarta Bay Reclamation and Policy Conflicts}

As is known, Jakarta Bay is a very large area, where in the region is rich in fishery products so that it becomes one of the suppliers of fish and other animal needs for the people of Jakarta. As a result of land requirements for shelter and trade investment, in 1995 President Soeharto's government issued a policy of implementing a reclamation project by issuing a Presidential Decree No. 52 of 1995 concerning the Reclamation of the North Coast of Jakarta. The regulation was established on July 13, 1995 which contained the determination of the North Coast Java reclamation as the only way of structuring and developing land and coastal space in order to realize the North Coast Region as a Mainstay Area, namely as an area that has strategic value viewed from an economic perspective and development of urban development [4].

In its implementation there are six development companies that have collaborated with the North Coast Management Agency to reclaim the Pantura Jakarta. These companies include PT. BaktiBangun Era Mulia, PT. Taman Harapan Indah, PT. ManggalaKridaYudha, PT. Pelabuhan Indonesia II, PT. Pembangunan Jaya Ancol and PT. Jakarta Propertindo. The six developers carried out reclamation activities without accompanied by an environmental impact analysis, resulting in the destruction of the marine ecosystem in the Bay of Jakarta.

The policy conflict began with the issuance of the Minister of Environment Decree Number 14 of 2003 concerning the Inadequacy of the North Coast Jakarta's Reclamation and Revitalization Plan. This regulation was then sued by six development companies that carried out the Jakarta Bay reclamation. The lawsuit was aimed at two main things, namely the Authority of the Minister of Environment to issue a decision on environmental inadequacy of the Jakarta pantura reclamation plan and the authority of the Minister of the Environment to require the authorized agency not to issue permits for North Coast Reclamation. In the trial process at the first and second level State Administrative Courts, the Panel of Judges granted the suit of the employers (Plaintiff). However, at the appeal level, the Panel of Judges successfully won the Minister of Environment and other Plaintiffs of Intervention. But at the level of the review, the Supreme Court actually won the entrepreneurs and revoked the cassation. Substance of the Judicial Review Decision stipulates the revocation of the legal status of the enactment of the environment minister's regulation so that the reclamation project continues. 
In its development, the government issued Presidential Regulation Number 54 of 2008 concerning Spatial Planning for the Areas of Jakarta, Bogor, Depok, Tangerang, Bekasi, Puncak, Cianjur. The regulation canceled Presidential Decree No. 52 of 1995 concerning Reclamation of the North Coast of Jakarta. With the revocation of the regulation, the Jakarta Bay reclamation project has no legal umbrella. As a result, the implementation of the reclamation project is back in trouble because the developer continues to carry out its activities regardless of protests from the community.

Surprisingly, regardless of the Presidential Regulation Number 54 of 2008, in 2012, the Jakarta Regional House of Representatives ratified the DKI Jakarta Regional Regulation Number 1 of 2012 concerning 2030 Spatial Planning. The regulation replaced Regional Regulation Number 6 of 1999 concerning Regional Spatial Planning The Special Capital City of Jakarta has expired in 2010. Based on this regulation, the North Coast Central Area is used as the location of a new development program for the DKI Jakarta provincial government. In fact, the North Coast Central Area is used as the Primary Activity Center area which serves international, national or several provincial activities. The North Coast Central Area is planned to become a new commercial center in the fields of trade, services, MICE (Meeting, Incentives, Convention, Exhibition), and financial institutions.

Meanwhile in 2015, development in the Jakarta Bay began extensively with the issuance of G Island, F Island, I Island and K. Island reclamation permits. The issuance of the permit extended the polemic of the reclamation project, because protests from the public grew increasingly massive so the Government finally stopped the continuation reclamation project. Even in 2016 the community was shocked by the arrest of one of the council members who was involved in a bribery case discussing plans for regional regulations related to reclamation by the Corruption Eradication Commission. Actually there are still around 13 islands that have not yet received reclamation permits from the Provincial Government of DKI Jakarta but the developers continue to carry out reclamation activities in the Jakarta Bay.

\section{Objective of the study}

This research investigates the Jakarta Bay reclamation policy which has a deadlock, covering how the north coast Jakarta reclamation policy from the perspective of existing regulations and what is the policy of the Governor of DKI Jakarta in implementing the Jakarta Bay reclamation project policy.

\section{Methodology}

This study uses a descriptive qualitative approach, which is to study the phenomenon of impasse in the implementation of Jakarta bay reclamation empirically. Data collection was carried out by in-depth interviews and literature review. Analysis is carried out with content analysis of the results of the in-depth interviews and regulations related to reclamation. The conclusion is carried out inductively based on data analysis.

\section{Discussion}

The Jakarta Bay reclamation project is still the status quo to this day or has a deadlock. This is due to the absence of policies that are aligned between the central and regional governments. Besides that there are many overlapping regulations and the many political interests of the actors as well as weak law enforcement. As a result, a number of islands that had already been built were stalled and most of the buildings that had been built also began 
to break down. This condition is influenced by the government's indecisiveness in taking policy.

Referring to the theory of Daniel A. Mazmanian and Paul A. Sabatier (1983) [5] which states that there are three groups of variables that influence the success of implementing a policy, namely tractability of the problems; ability of statute to structure implementation, and non statutory variables affecting implementation. The three groups of variables are interrelated so that the implementation of the policy can be known factors that influence the success or failure of a policy.

First, the characteristics of the problems that characterize the reclamation policy are economic interests, where investors play a very significant role. This is because the reclamation project requires a very large and sustainable investment, so that the existing policies are influenced by the interests of investors.

Therefore, it can be understood that the true mega reclamation project is only to satisfy capitalist interests, not for the benefit of the community around the reclamation project, let alone the interests of traditional fishing communities. This is because: First, the limited availability of land in Jakarta, plus the price that continues to rise high, causing investors to switch to reclaimed land. Investors in the property sector tend to choose to do beach reclamation rather than land acquisition. Second, capital owners tend to try to control resources exclusively, including the Jakarta Bay region, by changing into "elite city cities". In this perspective, instead of a reclamation project for the public interest, in turn it encourages the privatization of resources by groups of investors. The Jakarta Bay area which can be enjoyed by the public freely, will be converted into an exclusive area for the benefit of the capital owner group.

Secondly, the characteristics of policies or laws related to reclamation projects are not clear because Law Number 52 of 1995 concerning the North Coast Reclamation of Jakarta has been annulled with the issuance of Law Number 54 of 2008 concerning Spatial Planning for the Areas of Jakarta, Bogor, Depok, Tangerang, Bekasi, Puncak, Cianjur. This confusion is what triggers a prolonged policy conflict.

For example, the implementation of reclamation can be seen in the permit to implement Island G reclamation, which was issued in December 2014, mentioned several legal bases, including: Presidential Decree No. 52/1995 (concerning the North Coast Reclamation of Jakarta), Perpres No. 54/2008 (concerning Jabodetabekpunjur Spatial Planning), Perda No. 1/2012 (concerning the 2010-2030 Spatial Plan), Governor Regulation No.121 / 2012 (concerning Spatial Planning for North Jakarta Reclamation Area). Thus there are several laws as a higher regulation on Presidential Decree which is not used as a reference, namely Law No. 27/2007 concerning Coastal Zone article 7 paragraph 1 which requires zoning plans. This was reinforced by Perpres No. 122/2012 article 4 which states that the determination of the location of reclamation must be based on zoning plans for coastal areas and small islands [6].

Third, the characteristics of environmental variables that influence the reclamation project policy are political and bureaucratic factors. Both factors are very large. Reclamation projects also have an impact on the fishing communities who live and make a living on the North coast of Jakarta. The results of the study show the emergence of social problems in the fishing community, namely the disruption of social networking relations that have been formed for many years in fishing communities, starting from efforts to meet the living needs of fishing communities and develop into social capital in a small-scale fisheries business system. As a result, actors in social network relations that have been patterned have experienced changes to maintain the economic needs of their households. Thus there is an influence of the reclamation project on the decline in income of the fishing community north coast of Jakarta. 
The reclamation project in the end by the DKI Jakarta provincial government is often terminated but at other times it is run again with new regulations. This changing policy has caused the reclamation project to experience a deadlock, even there have been many lawsuits. The fishing community was finally made helpless by the policies of the central government and regional governments that were out of sync and tend to be elitist.

For example, the policy of Governor AniesBaswedan issued Governor Regulation No. 58 of 2018 concerning the Establishment of the Organization and Work Procedure of the Management Coordinating Board (BKP) of the North Coast of Jakarta Reclamation, has also caused a prolonged polemic regarding the Jakarta Bay reclamation project. This is because the issuance of the regulation is seen by the regional government of DKI Jakarta to continue the reclamation project, thus triggering rejection from the fishing community and environmental activists.

In Article 4 paragraph (1) Governor Regulation Number 58 Year 2018 states, that the North Coast Reclamation Management Coordinating Board in Jakarta has the task of coordinating the planning, implementation and supervision of the Jakarta Pantura Reclamation, the management of the Jakarta Pantura Reclamation, and the rearrangement of the north coast of Jakarta and provide policy recommendations in the management of the results of the Jakarta Pantura reclamation and the rearrangement of the north coast of Jakarta. Whereas pursuant to article 2 stated for the implementation of the tasks referred to in paragraph (1), BKP Pantura Jakarta organizes the coordinating function of organizing the Jakarta Pantura Reclamation. The word "implementation of reclamation" contained in article 4 paragraph (1) and (2) letter a gives a very strong impression that reclamation will continue, and this also gives the impression that Anies-Sandi has been inconsistent in the reclamation policy [7].

\section{Conclusion}

The implementation of the Jakarta Bay reclamation project policy has always been deadlocked because: First, the legal umbrella is unclear and regulations with overlapping contents. Secondly, the policies of the central government and regional governments are not synchronized in harmony, because of the sectoral ego of authority and the weak coordination between relevant institutions and departments. Third, the development of the Jakarta Bay reclamation area is not paying enough attention to environmental, economic, social and cultural aspects so that the community is rejected. Fourth, there are policy inconsistencies, so that reclamation projects are vulnerable to the interests of capital owners and political elite actors. Fifth, the implementation of the reclamation project raises many problems such as the absence of zoning plans and strategic area plans, the lack of clarity about the location of sand material retrieval, to the construction of houses and shop houses on the reclamation island without being preceded by a building permit (IMB), even without a land certificate.

\section{References}

1. F.M. Zaidiem. Reklamasi Jakarta Lautku Sayang, Lautku Hilang. Mengangkat Masalah Lingkungan Ke Media Massa (Yayasan Obor, Jakarta, 1995)

2. N. Sampono, A. Purbayanto, J. Haluan, A. Fauzi, Wiryawan, Budy, JPK 2, 105-112 (2012)

3. S. I. Sachoemar, H. D. Wahjono, JAI 3, 1-14 (2007)

4. Presidential Regulation No.52 of 1995 concerning Reclamation of the North Coast of Jakarta 
5. Mazmanian, A. Daniel, P. A. Sabatier. Implementation and Public Policy (Scott Foresman and Company, USA, 1983)

6. J. Sopaheluwakan, W. Hantoro, H. Warsilah, A. K. M. Kusumawijaya, R. T. Adi, R. Patters, B. Batubara, T. Hutapea, M. Hadiwinata, A. Kurniawaty, E. Sutanudjaja Makalah Kebijakan: Selamatkan Teluk Jakarta (Rujak Center for Urban Studies, Jakarta, 2017)

7. Governor Regulation Number 58 Year 2018 concerning the Establishment of the Organization and Work Procedure of the North Coast Reclamation Coordinating and Management Agency of Jakarta 